\title{
Compliance in the First Four Years of AAS 27 Financial Reporting by Local Government: A Study of the New South Wales experience
}

\author{
Gregory Kenneth Laing ${ }^{\dagger}$ \\ Faculty of Business, University of the Sunshine Coast
}

\begin{abstract}
This paper reports on a longitudinal study of the levels of compliance for the first four years (1994 to1997) following the introduction of the Australian Accounting Standard (AAS 27). The annual reports of all 177 local government councils in NSW were analysed revealing a high level of compliance with the standard. The main cause for non-compliance was the complexity of the recognition and treatment of assets. In addition a number of problems were identified, in particular the timeliness of the reports and the disproportionately high levels of depreciation expenses reported in the operating statement. The increased complexities of the financial management in Local Government imposed by AAS 27 required professional accounting competencies more appropriately derived from a degree level education which contributed to a high turnover of accounting staff during the four years. Finally, the paper questions the viability of the proposed dismantling of AAS 27 and the possible impact this might have upon the sector.
\end{abstract}

Key Words:

Local Government Accounting, Australian Accounting Standard 27, Financial Reporting Compliance

${ }^{\dagger}$ Corresponding author. Dr Gregory Kenneth Laing, Faculty of Business, University of the Sunshine Coast, Maroochydore DC QLD 4558. Email: glaing@usc.edu.au

*Acknowledgments:

This research was made possible by funding from CPA Australia.

\section{INTRODUCTION}

Financial reporting by local government, in Australia has now been operating on the accrual basis of accounting for some thirteen years (taking effect from $1^{\text {st }}$ July 1993). However, research since that time has tended to focus on specific aspects of the application of the local government accounting standard AAS 27 (Walker, Clarke \& Dean, 1999; Stepnick, 2001) and the implications for public sector reform (Hoque \& Moll, 2001; Klumpes, 2001). The literature prior to the introduction of the standard was of a normative nature that informed debate on the perceived negative aspects of the underlying assumptions of AAS 27 (Falk \& Neilson, 1993; Neilson, 1993), the cost of implementation and the questionable relevance of the information to the community and local government management (Spencer,1994: Cromrie \& Hope,1994). This paper seeks to address the gap in the literature by examining the four years following the introduction of the standard with the focus on compliance issues as they relate to the intended improvement of financial reporting. This review is timely in light of the proposed withdrawal of AAS 27 (Shying, 2006) and the experiences gained from the implementation period may help guide the conversion phase of accounting in the local government sector. 
Local government accounting has attracted the attention of researchers in other parts of the world. Berry and Jacobs (1981) examined the influence of external parties on the acceptance and subsequent compliance with accounting standards in the USA. The research focused on the extent to which external parties can influence the private sector as compared to the public sector, thereby providing insight into the driving forces for adoption and compliance. Ingram and Robbins (1987) conducted a survey of the disclosure practices of local government in the USA. They found that 75 percent of regulated cities conformed to GAAP (generally accepted accounting principles). Allen and Sanders (1994) conducted a similar survey and found that only seven years later, the level of acceptance had only slightly increased with 77 percent of the regulated cities conforming to GAAP. They concluded that greater attention and instructions were required to achieve uniformity in the accounting and reporting practices of local government throughout the USA.

The cash basis and related fund system of accounting has traditionally dominated local government accounting. A major problem with the cash basis of accounting was simply the way in which spending of funds was recorded without generating an appropriate asset base. In the UK attempts to change and standardise the accounting practices of local government started in the early part of the 1980s. Local government budgeting and its implications for financial administration became a focus for reform in the UK (Pendlebury,1994). The reasons were more to do with political control than better accounting methods (Baber and Sen, 1984). Parkes (1989) criticised the relevance of local government reporting in the UK; in particular the need for consistency and the adoption of a current cost basis of valuation for assets in particular infra-structure assets. The current cost basis of valuation was adopted in AAS 27 which requires assets be valued at their replacement cost. This approach is ideally suitable for local government because as providers of a set of definable services they are expected to offer those services continuously to the community ${ }^{1}$. Accordingly, the local government sector should be more concerned with the cost of replacing assets in order to maintain the services ${ }^{2}$.

\section{RESEARCH QUESTION AND DESIGN}

Lin, Baxter and Murphy (1993), proposed that a key determinant of the success in achieving improved financial reporting is the level of compliance. For the purpose of this study, compliance was measured by comparing the form and content of the financial reports with the appropriate sections of the standard. The level of compliance also included a measurement of the increase or decrease in the number of councils meeting the requirements of the standard from one financial year to the next. Areas of non-compliance were also identified where there was a failure to meet or satisfy specific requirements of the standard.

\footnotetext{
${ }^{1}$ See for example Martin (1988 476) for a discussion on the capital maintenance concept under 'current cost accounting' and the replacement cost (entry value) used for valuation of non-current assets. The replacement cost is justified under the going concern convention on the basis that "A continuing firm must maintain its operating capacity." The underlying notion implicit in this justification is that the firm will continue in the same business offering the same goods and or services and since local government can not cease to be in the same business of offering the same services to their constituents this model is ideally suited to their circumstances.

${ }^{2}$ A major reason for bankruptcy of local government in the USA was identified as budget deficits resulting from the need to replace ageing infrastructure (Park 2004). The current cost approach in local government focuses attention on the ability to maintain operating capacity and provides reports that are therefore relevant to the very nature of the councils operations. This is particularly relevant in Australia where the infrastructure of the major local government councils is reaching an age that will require replacement and upgrading.
} 


\section{METHODOLOGY}

The reports for each local government council in NSW were examined for compliance with the requirements for financial reporting stated in AAS 27: Financial Statements; Specific Issues. In this study analysis of the financial reports was made for the financial periods 1994, 1995, 1996 and 1997. Following the approach adopted by Lin, Baxter and Murphy (1993), a nominal figure was assigned to indicate compliance or non-compliance with each identified requirement. The number assigned to compliance was " 1 " and for noncompliance " 0 " thus providing a nominal score for statistical evaluation.

\section{SUBJECTS}

Local government councils in New South Wales were selected on the basis of availability, accessibility, and the degree of stability in the number of councils. Unlike other states (Victoria in particular) the councils were not merged or restructured during the period under investigation/review (Lawson, 1995). The financial reports for the one hundred and seventy seven (177) local councils in New South Wales were submitted to the NSW Department of Local Government in accordance with the state legislation (Local Government Act 1993). This department is responsible for checking compliance with state legislation and financial stability of each council and retaining an archival record of the financial reports.

\section{LIMITATIONS OF THE ANALYSIS}

Analysis of financial reports to determine compliance requires a subjective decision on the part of the researcher. While this limitation is acknowledged, the potential for bias was addressed by seeking expert advice on the matters affecting compliance and by research into the standard and its application. The researcher was cognisant of the specific differences and issues confronting local government accounting. Use of an instrument, in the form of a check list, to focus attention on the specific compliance requirements limited the potential for discovery of matters beyond the scope of the inquiry. The check list was pretested on a limited number of financial reports and submitted for comment by experts in the NSW Department of Local Government. As a result of the feedback, the instrument was amended.

Applying a nominal score to represent compliance or non-compliance is also subjective and errors may occur. To alleviate this potential problem, a pre-test post-test approach was used. The post-test was a review of the check list to test that the issues identified matched or exceeded those of the officers of the NSW Department of Local Government. The issues identified using the check list were consistent with those of the officers of the NSW Department of Local Government. The nominal scale also restricted the type and variety of statistical analysis that could be performed.

\section{RESULTS}

Compliance was based upon the requirements of the standard and classified into two main categories, the financial statements specifically required and the specific issues to be addressed in the financial statements. The findings with respect to the financial statements and the specific issues are summarised in Table 1. The compliance scores are presented in Table 2 for each year, together with an average for the four-year period. In addition, the compliance scores are totalled for each year and are also sub-totalled for the categories 'financial statements' and 'specific issues'. This is done to provide for comparison of the observed score against the expected score. 
The Australasian Accounting Business \& Finance Journal, May, 2007

Laing: Compliance in the first four years AAS 27. Vol. 1, No.2.

Table 1

Measures of Compliance with AAS Requirements

\begin{tabular}{|c|c|c|c|c|c|c|}
\hline Item & Topic & 1994 & 1995 & 1996 & 1997 & $\bar{x}$ \\
\hline & Financial Statements: & & & & & \\
\hline 1 & Operating Statement & 169 & 172 & 172 & 177 & 173 \\
\hline 2 & Statement of Financial Position & 170 & 165 & 168 & 175 & 170 \\
\hline 3 & Statement of Changes in Equity & 174 & 171 & 176 & 171 & 173 \\
\hline 4 & Statement of Cash Flow & 175 & 176 & 175 & 177 & 176 \\
\hline $\mathrm{T} 1$ & & 688 & 684 & 691 & 700 & 691 \\
\hline & Specific Issues: & & & & & \\
\hline 5 & Classification according to Nature or Type & 173 & 174 & 174 & 177 & 175 \\
\hline 6 & Classification according to Function or Activity & 174 & $* 162$ & 175 & 177 & 170 \\
\hline 7 & Restricted Assets & 176 & *147 & $* 134$ & 176 & 152 \\
\hline 8 & Conditions of Contributions & 176 & 176 & 176 & 177 & 176 \\
\hline 9 & Reporting on Compliance & 176 & 176 & 176 & 177 & 176 \\
\hline 10 & Performance Indicators & 175 & *136 & 175 & 177 & 162 \\
\hline 11 & Comparative Information & 175 & 174 & 174 & 177 & 174 \\
\hline 12 & Initial Application & 176 & 176 & 176 & 177 & 176 \\
\hline 13 & Recognition of Certain Assets & 172 & *162 & $* 164$ & 170 & 166 \\
\hline $\mathrm{T} 2$ & & 1,573 & 1,483 & 1,524 & 1,585 & 1,541 \\
\hline $\mathrm{T} 3$ & & 2,261 & 2,167 & 2,215 & 2,285 & 2,232 \\
\hline
\end{tabular}

$\mathrm{N}=177 ; \mathrm{T} 1=708 ; \mathrm{T} 2=1,593 ; \mathrm{T} 3=2,301$.

* Items which fluctuated or had notable non-compliance.

Table 2 presents a summary of the overall annual compliance rates as a percentage of the maximum compliance scores, which represent perfect compliance. The results are $98.3 \%$ in $1994 ; 94.2 \%$ in $1995 ; 96.3 \%$ in 1996 ; and $99.3 \%$ in 1997 , with the average for the four years of 97.0 percent. These results suggest that compliance was affected by the introduction of new recognition and reporting requirements. In 1995 problems associated with the implementation of the recognition of assets, not previously identified as a specific category, had a negative affect on compliance. 
Table 2

Compliance Rates Summarised

\begin{tabular}{|c|c|c|c|c|c|c|c|c|c|c|}
\hline & \multicolumn{2}{|c|}{1994} & \multicolumn{2}{|c|}{1995} & \multicolumn{2}{|c|}{1996} & \multicolumn{2}{|c|}{1997} & \multicolumn{2}{|c|}{$\bar{x}$} \\
\hline & Score & $\%$ & Score & $\%$ & Score & $\%$ & Score & $\%$ & Score & $\%$ \\
\hline Financial Statements: & 688 & 97.1 & 684 & 96.6 & 691 & 97.6 & 700 & 98.9 & 691 & 97.6 \\
\hline Specific Issues: & 1,573 & 98.7 & 1,483 & 93.0 & 1,524 & 95.7 & 1,585 & 99.7 & 1,526 & 95.8 \\
\hline Overall: & 2,261 & 98.3 & 2,167 & 94.2 & 2,215 & 96.3 & 2,285 & 99.3 & 2,232 & 97.0 \\
\hline
\end{tabular}

The details presented in Tables 1 and 2 indicate a high level of compliance for the four years with the overall rate of $97.0 \%$. However, due to changes in compliance requirements in each year, it is not strictly correct to assume that the 1994 results are the starting levels of compliance. The results indicate the level of non-compliance was directly related to recognition criteria specifically concerning the treatment of assets.

As a result the annual reports had accumulative compliance problems in the sense that the phase-in requirements from the previous period were outstanding in the subsequent period. In other words the results for each of the years may have been influenced by prior requirements. Regardless, failure to comply with any requirement, cumulative or otherwise, was considered to constitute non-compliance. The 1997 financial reports contained the least number of non-compliance scores and appear to indicate the culmination of the integration and adoption of the accounting requirements.

A comparative analysis of the trend in compliance over the four years shows how minor fluctuations occurred. The details are presented in Figure 1 and attention is drawn to the general increase in the 1997 financial year.

Figure 1

Trend Analysis of Compliance Scores

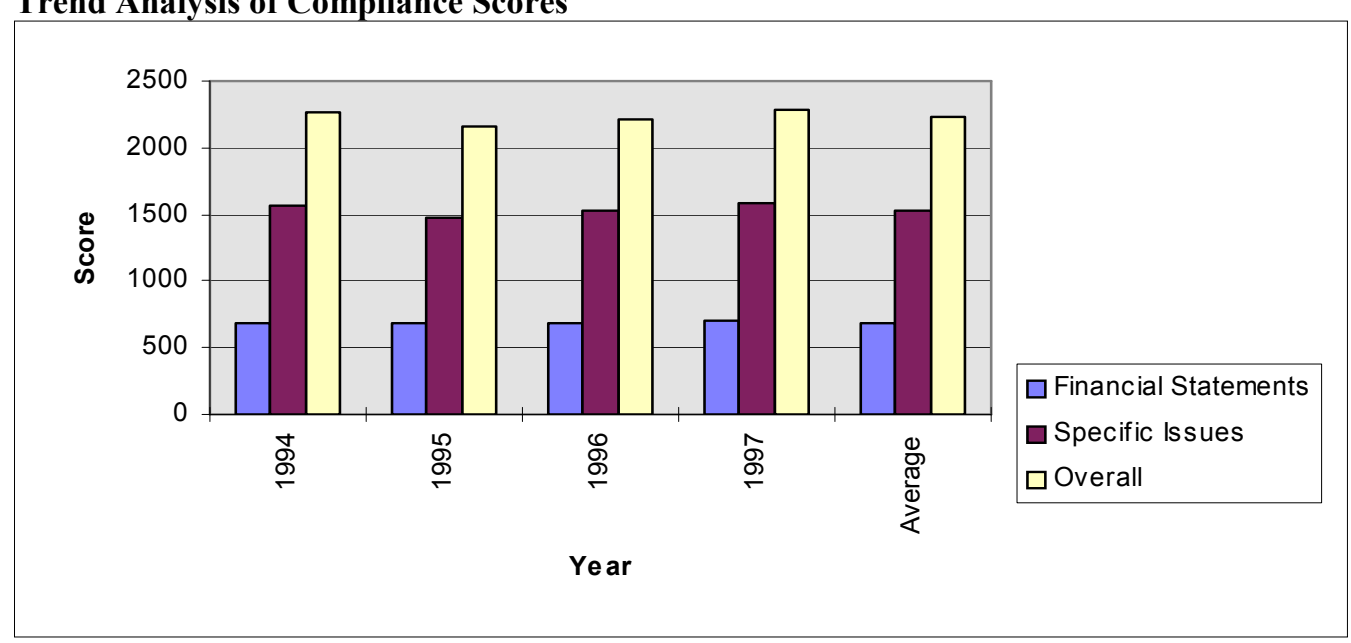


Implementation complexity during this transitional period means it is difficult to derive a statistical comparison of the level of compliance in terms of the increase or decrease in the compliance from one financial year to the next. Care should be taken in making any judgements about the differences in compliance given that there was a growth in the level of compliance over the four-year period. Table 3 lists the problems and anomalies encountered in the financial reports.

Table 3

Problems and Anomalies Encountered

\begin{tabular}{|r|l|r|r|r|r|}
\hline Item & Topic & 1994 & 1995 & 1996 & 1997 \\
\hline 1 & Late submission* & 73 & 36 & 41 & 14 \\
\hline 2 & Legal requirements & 13 & 20 & 12 & 14 \\
\hline 3 & Audit report qualified & 4 & 3 & 1 & 4 \\
\hline 4 & Audit report adverse & 8 & 72 & 47 & 0 \\
\hline 5 & Notes incorrect or irrelevant & 7 & 59 & 44 & 1 \\
\hline 6 & Assets incorrectly dealt with & 3 & 1 & 1 & 0 \\
\hline 7 & Liabilities incorrectly dealt with & 43 & 1 & 0 \\
\hline 8 & Did not state who performed asset valuation & 1 & 33 & 1 & 0 \\
\hline 9 & Did not stipulate materiality threshold & 1 & 38 & 1 & 0 \\
\hline 10 & Did not identify specific purpose grants & 1 & 1 & 2 & 0 \\
\hline 11 & Did not apply lower of cost or net realisable value to real estate & 1 & 38 & 1 & 0 \\
\hline 12 & S413 certificate missing or incomplete & 6 & 3 & 0 \\
\hline 13 & Auditor error & 1 & 1 & 1 \\
\hline
\end{tabular}

* Deemed late by reason of not seeking or failing to meet time limits granted by extension.

The most prevalent of the problems identified in Table 3 concerned the recognition and treatment of assets. In addition, the recognition of liabilities presented problems for the councils as did the appropriateness of adhering to the reporting requirements of a general accounting nature. From the reports it was noticeable that over the four year period there was a $34.5 \%$ change in the responsible senior financial officer (accountant) at the councils. Upon investigation, the explanations for this high turnover rate pointed to retirement (approximately three-quarters) with the remainder having either transferred to another department/area in council or opted for employment outside of local government. Interviews with council officers identified that the complex nature of the changes to the accounting system were the major reason for the high staff turnover. This is consistent with the findings of Cheng, Engstrom and Kattelus (2002) that the increased complexities of financial management in Local Government required professional accounting competencies more appropriately derived from a degree level education. 


\section{DISCUSSION}

The transitional aspects of the application of the accounting standard caused problems with regard to compliance. As additional recognition requirements were introduced the councils appeared to incur difficulties attributable to the intricacies of dealing with such accounting requirements.

This study identified some specific problems relating to non-compliance, in particular the measurement of assets and liabilities and specifically the accounting treatment of non-current assets. For example, there were councils whose financial statements had the extraordinary situation of depreciation expense representing up to $67 \%$ of the total expenses. When considering that the majority of users of these reports, such as rate payers, are less likely to be fully conversant with the sophisticated concepts of accounting the notes to the financial reports become a very important component of the overall reporting.

Examination of the financial statements provided empirical evidence regarding the levels of compliance and the major areas of non-compliance during implementation. Accounting for physical (non-current) assets represented the major reporting problem. Another problem, identified in Table 3 item 1 was the number of late submissions, this time lag between the end of the accounting period and the issue of the report undermined the usefulness of the financial information. However, the trend was for continued +reduction of the time lag, and by 1997 the number of non-compliant councils had reduced to 14 .

The high staff turnover was according to anecdotal evidence a result of the major changes required of the financial accounting systems. The change in educational requirements identified in job advertisements during that period, for staff in the accounting departments, indicated a major shift to formal accounting qualifications, where once the Town Clerk's certificate or diploma had been the standard. The change to the accounting practices as a result of the introduction of AAS 27 appears to have been inadequately planned for in terms of human resource management. The complex nature of the accounting systems and reporting requirements required by AAS 27, resulted in high turnover of incumbent local government staff, who were not sufficiently qualified to administer the increased complexity of the new accounting standard.

The implementation of AAS 27 was a major transition in local government, with the introduction of accrual accounting, replacing the cash based approach and the implementation of the current cost model for the valuation of assets rather than the historical cost model. The proposal to now dismantle AAS 27 and apply the international accounting standard's approach is likely to cause yet another upheaval in local government. In particular the move from the current cost model for valuing assets to the fair value model does not seem to take into consideration the appropriateness that replacement cost has in the local government sector. After all the purpose of local government is to provide services to their constituents and they are hardly commercial entities that can chop and change the services they provide so the focus of the financial reports should be on their ability and capacity to continue to maintain those services. Subjecting local government to yet another major change is likely to result in confusion especially for the constituents who less likely to posses the sophisticated knowledge required to analyse and interpret the financial reports. Increased demands on resources can also be expected in particular the need for qualified accounting staff. With qualified accounting staff being in short supply in the current employment climate 
councils will have to offer higher salaries to be competitive and the smaller councils may not have the capacity to accommodate this increased demand on resources.

\section{REFERENCES}

Allen, A. and Sanders, G.D. (1994), 'Financial Disclosure in US Municipalities: Has the Governmental Accounting Standards Board Made a Difference?', Financial Accountability \& Management, 10(3), 175-193.

Baber, W.R. and Sen, P.K. (1984), 'The Role of Generally Accepted Reporting Methods in the Public Sector: An Empirical Test', Journal of Accounting and Public Policy, 3(2), 91-106.

Berry, L.E. and Jacobs, F.A. (1981-82), 'Government Accounting Standards: The Compliance Issue', Government Accountants Journal, Winter, 30-36.

Cromrie, J and Hope, D. (1994), A Post-implementation Review of AAS27 - Financial Reporting for Local Governments, International Accounting Conference, November 1994, Adelaide.

Falk, H. and Neilson, J. (1993), 'Financial Reporting by Local Government and the Disproportionate Requirements of AAS 27, Australian Accounting Review, 3(2), 55-61.

Hoque, Z. \& Moll, J. (2001), 'Public Sector Reform: Implications for Accounting, Accountability and Performance of State-owned Entities - An Australian Perspective', Accounting, Auditing \& Accountability Journal, 14(4), 304-326.

Ingram, R. W. and Robbins W.A. (1987), Financial Reporting Practices of Local Governments, Research Report (Stamford, Ct.: Governmental Accounting Standards Board, 1987).

Klumpes, P. (2001), 'Generational Accountability of Public Sector Management: A case study of the State Authorities Superannuation Board of New South Wales', Accounting, Auditing \& Accountability Journal, 14(2), 166-189.

Lawson, M. (1995), 'Local Government - It's an era of mergers', Financial Review, November 20, 39.

Lin, Z.J., Baxter, G.C. and Murphy, G.J. (1993), 'Improving Government Financial Reporting in Canada: An Evaluation of Compliance with the PSAAC'S Accounting and Reporting Standards for Governments', Financial Accountability \& Management, 9(4), pp.235-254.

Local Government Act (1993).

Martin, C. (1988), An Introduction to Accounting $2^{\text {nd }}$ Edn., McGraw-Hill: Sydney.

Park, K. (2004), 'To File or Not to File: The Causes of Municipal Bankruptcy in the United States', Journal of Public Budgeting, Accounting \& Financial Management, 16(2), 228-256.

Neilson, J. (1993), 'AAS 27: Expensive \& Unnecessary', Charter, March, 53-57.

NSW Department of Local Government (1996), 'Local Government Code of Accounting Practice and Financial Reporting'.

Parkes, J. (1989), 'Local Authority Capital Accounting - Towards Reform', Financial Accountability \& Management, 5(2), 107-119.

Pendlebury, M.W. (1994), 'Management Accounting in Local Government', Financial Accountability \& Management, 10(2), 117-129.

Shying, M. (2006), 'Withdrawal of government specific standards', Intheblack, February, 59-60.

Spencer, J.D. (1994), ‘AAS 27 - The First Year: What Have We Achieved?', Paper presented at Local Government Auditors Association of NSW Seminar, Canberra, July.

Stepnick, E.W. (2001), 'Changes in Accounting Standards for Capital Assets can help to Preserve the Infrastructure', Journal of Government Financial Management, 50(3), $42-49$.

Walker, R.G., Clarke, F.L. \& Dean, G.W. (1999), 'Reporting on the state of infrastructure by local government', Accounting, Auditing \& Accountability Journal, 12(4), 441-458. 